\title{
Differentiation for the Gifited in American Islamic Schools
}

\author{
Fatma A. K. Al-Lawati \\ Ministry of Education \\ Sultanate of Oman
}

\author{
Scott L. Hunsaker \\ Utah State University
}

This research focuses on teacher instructional and curricular practices in gifted students' experiences in Islamic schools in the United States. Surveys were administered at private, full-time Islamic elementary schools to determine the extent to which differentiation practices for meeting the needs of gifted students and the integration of Islamic values were employed. Findings suggest that Islamic schools in the United States have limited programs for gifted students. A majority of teachers in Islamic schools differentiate little between gifted and average students in instructional strategies. When differentiation occurs, it is very basic. Further, teachers at Islamic schools generally do not integrate Islamic values into otber academic areas and present them to all students without differentiation.

The research base for differentiation shows that it has a positive impact on student achievement. Children who are in special gifted programs, including within-class programs that use differentiated curriculum strategies, have shown substantially higher achievement levels than their gifted peers not attending a gifted program (Delcourt, Loyd, Cornell, \& Goldberg, 1994). Purcell (1993) has indicated that when differentiation provided by the gifted program was eliminated, students (a) experienced a decline in motivation to achieve at the high levels of which they were capable, and (b) began to underachieve on the traditional curriculum. A large-scale national study has suggested that classroom teachers make only very minor

Fatma Anwer Al-Lawati is an educational expert in the Ministry of Education in the Sultanate of Oman. Scott L. Hunsaker is Associate Professor of educational foundations and gifted and talented education in the Department of Elementary Education at Utah State University.

Journal for the Education of the Gifted. Vol. 30, No. 4, 2007, pp. 500-518. Copyright (2007 Prufrock Press Inc., http://www.prufrock.com 
modifications in their teaching for gifted students (Archambault et al., 1993a). Follow-up research conducted by the National Research Center on the Gifted and Talented (NRC/GT) suggested that gifted and talented students receive a limited amount of curriculum differentiation regardless of the subject area being taught (Westberg, Archambault, Dobyns, \& Salvin, 1993). Gifted students spent $84 \%$ of the time in activities that involve no differentiation experiences. A study by Gentry, Gable, and Springer (2000) supported the Archambault et al. (1993a) and Westberg et al. (1993) findings. It indicated that gifted middle school students did not have an opportunity to participate in problem-solving activities or other activities that aroused their curiosity and that they rarely were given any choices. Their attitudes toward school were essentially the same as their nonidentified classmates. In other words, differentiation did not occur for any student on any particular dimension-ability, interest, or need.

A recent study conducted by Johnsen, Haensly, Ryser, and Ford (2002) indicated that classroom teachers could learn to make changes in their instructional practice that would be more responsive to the needs of gifted-level learners. Where those changes were more transformational (i.e., significant and numerous alterations of classroom practices), students experienced "more satisfaction with school, increases in confidence, feelings of acceptance, and selfesteem" (p. 61). Where changes were merely conservational (i.e., supporting what the teacher was already doing), students reported little or no satisfaction.

The need for differentiation is likely present among gifted students regardless of their placement in public or private schools or whether their schools are based on religious or secular principles. A key difference between the religious and secular schools, however, is that religious private schools come with a doctrinal foundation that would necessarily guide decisions about differentiation for gifted students, in addition to guidance from research. This article seeks to address this difference through an investigation of differentiation in one rapidly expanding segment of the private school population in the United States, namely, Islamic private schools. 


\section{The Value of Education in Islam}

A database review indicated that few research studies have been carried out in Islamic schools. One example, however, is a recent study in which Elsegeiny (2005) studied the leadership style of principals in Islamic schools in the United States. When Elsegeiny compared his findings to prior research on the leadership styles of principals, he suggested that the leadership characteristics of Muslim principals in Islamic schools was very similar to those of other U.S. principals.

In other studies, Elkhaldy (1996) and Badawi (2005) explored parents' reasons for enrolling their children in Islamic schools. Their findings indicated that religious education and Islamic environment are the primary reasons for parents enrolling their children in Islamic schools. According to Istanbouli (2000), "Muslim parents in the United States are faced with the dilemma of wanting their children to be 'Americans' involved in all spheres of American life.... At the same time they want their children to be 'good Muslims." (p. 2). Muslim students, as members of the Muslim community on one hand and as American citizens on the other hand, are expected to be able to find balance between their rights and responsibilities (Selby, 1994).

According to Clark (2002), "Giftedness at the highest level can be found in every cultural group" (p. 497). In the United States, there are approximately 250-300 Islamic schools. Gifted education is critical within these schools to develop the abilities of Muslim students because it is likely that among these students there are some who could be expected to contribute and lead Islamic society in America in order to provide a better understanding of Islamic values and norms in the context of the greater American society, to the benefit of both the Islamic community in America and of the nation in general. In America's diverse culture, anything that strengthens the talents of any particular cultural subgroup must necessarily strengthen the culture as a whole.

The call for education and acquiring knowledge in Islam is based on its significant role in modifying a person's humanity and its impact on the social life of human beings. Therefore, Islam encourages its followers to pursue knowledge. The importance of acquiring knowledge is implied in the first revelation, "Proclaim! (or read!) In the name Of 
thy Lord and Cherisher who created" (96:1). ${ }^{1}$ Islam treats the act of acquiring education as an act of worship. Hence, Muslims, regardless of their race or gender, are obligated to pursue knowledge. The Hadith (sayings of the Prophet Mohammad [pbuh]) ${ }^{2}$ says, "Seeking knowledge is a duty on every Muslim man and woman" (Parker-Jenkins, 1995, p. 37). Therefore, at Badr, the first Islamic battle against nonbelievers, each hostage from the battle was asked to teach $10 \mathrm{Muslim}$ men in order to gain his freedom. Moreover, the first public school in the Arabian Peninsula was established in the Prophet Mohammad's (pbuh) mosques (Al-Otaibi \& Rashid, 1997). Islamic rulers established schools and colleges that were accessible to everyone in the community, whether rich or poor, even to slaves (Khan, 1983).

The importance of this study stems from the presence of gifted students in all educational settings-public or private. Any principle of gifted education formed in one setting would be expected to hold in other settings. One would also expect that differentiation practices would be effective in all content areas including religious studies-a dimension often included in religious private school curricula. While no research studies have documented the mobility of principles suggested here, this research begins to explore the state of the art, so that these propositions can be tested. This research, therefore, explores the state of differentiation for gifted students in Islamic schools in the United States. Because the practices of gifted education are more researched at the elementary school level, this research investigates differentiation for the gifted at this level. The focus of this study is on teachers' daily practices in planning and implementing the curriculum for gifted and average students in Islamic schools in the United States. The following research questions were investigated:

1. Do teachers in the regular classroom in Islamic schools modify their practices and differentiate the curriculum to meet the needs of gifted students? Are there differences in these practices for the two groups of gifted and average students?

2. Do Islamic values and the Muslim culture have any impact on gifted students in Islamic schools? Specifically, do the teachers integrate the Islamic values in their services for gifted students? 


\section{Method}

\section{Participants}

Participants in this study were elementary school teachers $(N=157)$ in Islamic schools across the United States. The sample of teachers came from schools in 23 states; 8 west of the Mississippi and 15 east of the Mississippi. All Islamic schools in the United States are nonprofit organizations that are developed to serve the Islamic community in the respective states. These schools are similar to American public schools in terms of their organization and structure. The small differences between the Islamic schools and the public American schools are in some of the subjects offered, such as Arabic Language and Islamic Studies. (K. Kayworth, personal communication, June 13, 2002).

The participants in this study consisted of a volunteer sample of elementary Islamic school teachers. Women dominate the teaching field in Islamic schools. Further, $90 \%$ of teachers identify themselves as Muslims; only 33.6\% listed themselves as Middle Eastern. Caucasian Americans and Asian Americans comprised other large groups represented, with percentages of $22 \%$ and $20 \%$ respectively. The majority of the Islamic school teachers in the sample have received a bachelor's degree as the highest degree earned. While opportunities for training in gifted education had been available to $49 \%$ of the teachers, $44 \%$ of the 157 teachers had not received any kind of training. The two most common forms of training were courses at a college or university (27\%) and workshops (26\%). Nearly $40 \%$ of the Islamic school teachers in this study have fewer than 5 years of experience in teaching, while about $10 \%$ of the teachers have more than 19 years of teaching experience. The majority of the teachers taught in an intact or self-contained classroom. Most of the responding teachers were assigned to primary grades, with $39 \%$ of the sample teaching kindergarten through second grade and $23 \%$ teaching grades 3-6. It is also interesting to note that about $38 \%$ of the teachers in Islamic schools teach in combined classes.

The average class size in the participating Islamic schools was about 19. The mean number of females in each class was 10.5 . 
However, the standard deviations indicate that there is a great deal of variability in gender mix from class to class (i.e., Male, $S D=4.97$; Female, $S D=6.3$ ). Almost no non-Muslim students were enrolled in these schools.

\section{Instruments}

The Classroom Practices Questionnaire. The Classroom Practices Questionnaire (CPQ; Archambault et al., 1993b) was developed by the National Research Center on the Gifted and Talented (NRC/ GT) in cooperation with Market Data Retrieval. The CPQ consists of four sections that solicit information about (a) teachers' backgrounds, (b) gifted education policies adopted by the school, (c) classroom issues faced by the teachers, and (d) participants' practices with gifted and nongifted students in his or her classroom. Alpha reliabilities for these sections range from .53 to .83 . Items in each of the sections employ a Likert-type scale, ranging from 0 (never) to 5 (more than once a day). However, no validity information was provided by the authors of the CPQ.

\section{The Scale for Rating Teacher's Curriculum Practices in Applying} Islamic Value. The Scale for Rating Teacher's Curriculum Practices in Applying Islamic Value (TCPAIV) was developed according to the format of the CPQ in order to rate the teachers' behavior toward applying Islamic values in the classroom. The questionnaire seeks information about how teachers integrate Islamic values while teaching gifted and nongifted students in the regular classroom. The items were divided into four sections: (a) The Ultimate Source of Knowledge; (b) The Ethical Framework; (c) The Believer to Act Upon Knowledge; and (d) Environmental Aspects. Educators, either from general education or gifted education, and Muslim scholars were asked to review the instrument in order to determine the content and face validity. In addition, a pilot study was carried out in four Islamic schools in Canada to evaluate the instrument's reliability. It was found that most teachers indicated that they do not modify their curriculum practices to meet gifted students' needs. Therefore, the questionnaire's reliability was calculated based only 
on the information that was gathered from teachers' responses in the average students' column. The overall alpha reliability for the instrument was .96. Each section's reliability was also high: (a) The Ultimate Source of Knowledge $(\alpha=.93)$; (b) The Ethical Framework $(\alpha=.90)$; (c) The Believer to Act Upon Knowledge $(\alpha=.88)$; and (d) Environment Aspects ( $\alpha=.74$ ). Thus, all alpha reliabilities are in an acceptable range for an instrument of this type.

\section{Procedure}

Numerous efforts were made through phone calls to invite Islamic schools to participate in the study. Ultimately, 47 Islamic schools accepted the invitation letters and returned them with the needed information. Based on the information that was received from the Islamic schools regarding the number of the classes in each grade level and the number of teachers who were interested in participating in the study, 408 packages were sent to the 47 schools. The package included an individual envelope for each teacher interested. The teacher envelope included a survey, an informed consent form, a postcard from the first author's country as a token of appreciation, a thank-you letter, and a prepaid return envelope.

Packets from 161 teachers at the elementary school level were received. All schools that participated in the study were private fulltime Islamic schools in the United States. After reviewing the returned questionnaires, four were eliminated mainly because the participants were not K-6 grade-level teachers. The eliminated questionnaires included two completed by principals and one by a preschool teacher. The fourth questionnaire was not filled out at all. Therefore, the sample of this study consists of 157 teachers (38\% return rate).

\section{Results}

\section{Differentiating Practices}

Approximately $74 \%$ of the teachers in Islamic schools believed they had gifted students in their classroom. Interestingly, only about $27 \%$ 


\section{Table 1}

\section{Provision of Information on Both Gifted and Average Students by Teachers Who Claim to Differentiate}

\begin{tabular}{lcccccc}
\hline & \multicolumn{2}{c}{ Gifted only } & \multicolumn{2}{c}{ Average only } & \multicolumn{2}{c}{ Both } \\
\cline { 2 - 7 } Surveys & $f$ & $\%$ & $f$ & $\%$ & $f$ & $\%$ \\
\hline Teachers $(n=73)$ & & & & & & \\
Instruction practices & 3 & 4.11 & 6 & 8.22 & 64 & 87.67 \\
Curriculum practices & 6 & 8.22 & 2 & 2.74 & 58 & 79.45 \\
\hline
\end{tabular}

had gifted students who had been formally identified, while nearly $64 \%$ of the teachers believed that they had gifted students who had not been formally identified. Only about $13 \%$ of the teachers indicated that they did not know whether they had any gifted students.

Although a majority of teachers indicated having formally or informally identified gifted students in their classroom, only about $60 \%$ of them indicated that they modified their practices to meet gifted students' needs. Furthermore, four teachers who claimed not to have any gifted students in their classrooms indicated that they modified their practices, whereas $29 \%$ of the teachers indicated they did not modify their classroom practices. Another 10\% claimed that differentiation was not relevant to their classroom practice.

Data from the $60 \%$ ( 73 teachers) who stated that they modify their practices to meet gifted students needs were further examined. The study aimed to compare teachers' practices with gifted and nongifted students in their classroom. It was expected that all 73 teachers would provide information on their practices with both their gifted and their average students. Out of 73 teachers, approximately $88 \%$ of the teachers provided information on both gifted and average groups on the CPQ, while $79 \%$ provided information on both groups on the TCPAIV (see Table 1).

The data were further analyzed using the SPSS statistical processing package in the following ways:

1. Teachers' responses to the average column and the gifted column for each item were compared and coded into three categories; (a) gifted high; (b) average high; and (c) no 
differences. So if a teacher reported a higher frequency of strategy use for gifted students, the item was coded "gifted high" and likewise for the average side. However, if the reported frequency of strategy use was the same for gifted and average students, the score was coded "no differences."

2. Information was further analyzed by calculating the means, standard deviation, effect size, and p-values of $t$ tests for each of the items.

\section{Classroom Differentiation}

The majority of teachers do not differentiate in their use of strategies between gifted and average students. They generally offer the same types of instruction to the gifted as well as to average students. However, most Islamic school teachers reported that they use advanced-level readings more frequently with gifted students than with average students (see Table 2). This was the only practice in which "No differences" was not in the majority.

For a different approach to understanding the data, the means, standard difference, effect size, and $p$-values of $t$ tests were calculated for each of the items, testing for significant differences. The paired $t$-test results reveal that approximately $50 \%$ of the items show statistically significant mean differences at the level of $\alpha=.05$. The magnitude of the difference between the means was calculated by dividing the mean difference for each item by the standard deviation of the average group for that item. It ranged from .95 to .18 . In addition, for an independent $t$ test, the probability of getting a Type I error is $\mathrm{P}=$ $1-(1-\alpha)^{c}$ where $c=$ the number of items tested (Glass \& Hopkins, 1995). This CPQ consisted of 39 items. Thus, the probability of at least one Type I error occurring would be .86. This means that it is likely that there is at least one Type I error among the 20 items found to be statistically significant.

As a further guard against Type I error, the Holm-Bonferroni sequential procedure was applied (Aickin \& Gensler, 1996). This procedure requires sequential testing of the $p$ level for each $t$ test using $\alpha /(n-i+1)$ as the equation for parsing the alpha level among the various tests, where $n$ is the number of tests conducted (in this case 39) 


\section{Table 2}

\section{Frequency and Percentage of Teachers' Responses to the CPQ Items for Gifted and Average Students}

\begin{tabular}{|c|c|c|c|c|c|c|c|}
\hline \multirow[b]{2}{*}{$\#$} & \multirow[b]{2}{*}{ Item } & \multicolumn{2}{|c|}{ Gifted high } & \multicolumn{2}{|c|}{ Average high } & \multicolumn{2}{|c|}{ No differences } \\
\hline & & $f$ & $\%$ & $f$ & $\%$ & $f$ & $\%$ \\
\hline \multicolumn{8}{|c|}{ Teachers $(n=64)$} \\
\hline 3 & Assign advanced level reading & 38 & 59.4 & 3 & 4.7 & 18 & 28.1 \\
\hline 15 & Different work for students & 28 & 43.8 & 2 & 3.1 & 30 & 46.9 \\
\hline 2 & Use enrichment worksheets & 28 & 43.8 & 1 & 1.6 & 31 & 48.4 \\
\hline 27 & Textbook for higher grade level & 23 & 35.9 & 3 & 4.7 & 35 & 54.7 \\
\hline 6 & Assign projects & 20 & 31.3 & 3 & 4.7 & 37 & 57.8 \\
\hline 11 & Time for self-selected interests & 20 & 31.3 & 1 & 1.6 & 41 & 64.1 \\
\hline 28 & More advanced curricular unit & 19 & 29.7 & 1 & 1.6 & 40 & 62.5 \\
\hline 13 & Eliminate material mastered & 18 & 28.1 & 2 & 3.1 & 39 & 60.9 \\
\hline 7 & Assign book reports & 18 & 28.1 & 1 & 1.6 & 40 & 62.5 \\
\hline 5 & Assign reports & 17 & 26.6 & 2 & 3.1 & 40 & 62.5 \\
\hline 23 & Teach a unit on thinking skills & 16 & 25.0 & 1 & 1.6 & 43 & 67.2 \\
\hline 10 & Creative writing student topic & 15 & 23.4 & 2 & 3.1 & 42 & 65.6 \\
\hline 19 & Homework based on ability & 14 & 21.9 & 5 & 7.8 & 44 & 68.8 \\
\hline 33 & Programmed materials & 14 & 21.9 & 4 & 6.3 & 42 & 65.6 \\
\hline 17 & Locations around classroom & 14 & 21.9 & 1 & 1.6 & 48 & 75.0 \\
\hline 4 & Use self-instructional kits & 13 & 20.3 & 4 & 6.3 & 35 & 54.7 \\
\hline 9 & Creative writing teacher's topic & 12 & 18.8 & 3 & 4.7 & 44 & 68.8 \\
\hline 8 & Use puzzles or word searches & 12 & 18.8 & 1 & 1.6 & 44 & 68.8 \\
\hline 21 & Use enrichment centers & 12 & 18.8 & 1 & 1.6 & 45 & 70.3 \\
\hline 24 & Competitive thinking skills & 12 & 18.8 & 1 & 1.6 & 46 & 71.9 \\
\hline 34 & Encourage long-range projects & 11 & 17.2 & 3 & 4.7 & 45 & 70.3 \\
\hline 36 & Ask open-ended questions & 11 & 17.2 & 1 & 1.6 & 51 & 79.7 \\
\hline 25 & Contracts for independent study & 10 & 15.6 & 4 & 6.3 & 46 & 71.9 \\
\hline 35 & Encourage reasoning & 10 & 15.6 & 1 & 1.6 & 49 & 76.6 \\
\hline 22 & Thinking in the curriculum & 9 & 14.1 & 3 & 4.7 & 51 & 79.7 \\
\hline 30 & Higher grade for instruction & 9 & 14.1 & 2 & 3.1 & 46 & 71.9 \\
\hline 16 & Modifying instruction & 8 & 12.5 & 10 & 15.6 & 43 & 67.2 \\
\hline 29 & Group by ability & 8 & 12.5 & 5 & 7.8 & 48 & 75.0 \\
\hline 20 & Learning centers for basic skills & 8 & 12.5 & 2 & 3.1 & 50 & 78.1 \\
\hline 31 & Establish interest groups & 8 & 12.5 & 2 & 3.1 & 44 & 68.8 \\
\hline 38 & Encourage discussions & 8 & 12.5 & 1 & 1.6 & 52 & 81.3 \\
\hline 12 & Pretests to determine mastered & 7 & 10.9 & 3 & 4.7 & 52 & 81.3 \\
\hline 18 & Work in other locations & 7 & 10.9 & 2 & 3.1 & 51 & 79.7 \\
\hline 32 & Allocating time & 7 & 10.9 & 1 & 1.6 & 53 & 82.8 \\
\hline 26 & Time for independent study & 6 & 9.4 & 3 & 4.7 & 50 & 78.1 \\
\hline 1 & Use basic skills worksheets & 5 & 7.8 & 11 & 17.2 & 44 & 68.8 \\
\hline 39 & Use computers & 5 & 7.8 & 3 & 4.7 & 53 & 82.8 \\
\hline 14 & Repeat difficult concept & 4 & 6.3 & 24 & 37.5 & 34 & 53.1 \\
\hline
\end{tabular}

Note. $f \doteq$ Frequency. 
and $i$ is the position of the item in sequence from the least to the greatest $p$ level. Using this procedure, only the first five items listed (Items 3, $2,15,14,11$ ) are considered to be significant (see Table 3 ). However, Roback and Askins (2005) have suggested that the use of such procedures may be too conservative when the research is more exploratory than confirmatory. Such may be the case for this research. Because this is a first effort to investigate differentiation in Islamic schools, we will interpret the data from the broader perspective permitted by the Glass and Hopkins (1995) procedure, but provide the Holm-Bonferroni data to permit readers to draw their own conclusions.

The data indicate that Islamic school teachers are more likely to focus on enrichment and acceleration activities for gifted students that emphasize reading and writing assignments (Items 2, 3, 6, 7, 5 , and 10). Islamic school teachers were also found to provide their students with some activities that involve critical thinking skills (Items $23,8,24,36$, and 37 ). Some teachers indicated that they modify their curriculum to differentiate based on individual learner's profiles (Items 15, 13, 19, and 28). They are less likely to involve gifted students in activities that involve questioning skills or challenging independent work (see Table 3).

The effect size was also computed for each item to determine the practical significance of the differences between two means. According to Cohen's rule of thumb, an effect size of .20 is considered small, an effect size of .50 is moderate, and an effect size of .80 is characterized as large (Howell, 2002). Thus, for the data shown in the Table 3, effect sizes ranges from less than small to greater than large.

Although 20 of the 39 items on the CPQ were found to have significant differences at $\alpha=.05$, a close look at the effect sizes indicates that Islamic school teachers differentiate only in basic ways. For example, there is a very large effect size for assigning reading of more advanced level work $(d=.95$, Item 3$)$ and a nearly large effect size for using enrichment worksheets $(d=.74$, Item 2$)$. A moderate effect size was found for substituting different assignments for students who mastered regular classroom work ( $d=.48$, Item 15$)$. One other item, repeated difficult concepts (Item 14), also yielded a moderate effect size $(d=-.51)$; this activity was more likely to be used with average students than with gifted students (see Table 3 ). 


\section{Table 3}

\section{Mean Differences, Standard Deviation, Effect Size, and Level of Significance of Teachers' Responses to the CPQ Items for Gifted and Average Students}

\begin{tabular}{|c|c|c|c|c|c|c|c|c|}
\hline$\#$ & Items & $\begin{array}{c}\text { Gif- } \\
\text { Ave }^{2} \\
M\end{array}$ & $\begin{array}{l}\text { Gif- } \\
\text { Ave }^{2} \\
S D\end{array}$ & $E S$ & $d f$ & $t$ & $p$-value & $\begin{array}{c}\text { Adjusted } \\
\alpha\end{array}$ \\
\hline 3 & Assign advanced level reading & 1.22 & 1.49 & 0.95 & 58 & 6.31 & 0.000 & .001 \\
\hline 2 & Use enrichment worksheets & 0.87 & 1.22 & 0.74 & 60 & 5.57 & 0.000 & .001 \\
\hline 15 & Different work for students & 0.72 & 1.26 & 0.48 & 59 & 4.39 & 0.000 & .001 \\
\hline 14 & Repeat difficult concepts & -0.76 & 1.34 & -0.51 & 62 & -4.51 & 0.000 & .001 \\
\hline 11 & Time for self-selected interests & 0.38 & 0.85 & 0.26 & 62 & 3.56 & 0.001 & .001 \\
\hline 28 & More advanced curricular unit & 0.53 & 1.29 & 0.33 & 59 & 3.19 & 0.002 & .001 \\
\hline 6 & Assign projects & 0.52 & 1.27 & 0.37 & 60 & 3.22 & 0.002 & .002 \\
\hline 27 & Textbook for higher grade level & 0.67 & 1.69 & 0.36 & 60 & 3.11 & 0.003 & .002 \\
\hline 5 & Assign reports & 0.45 & 1.14 & 0.33 & 59 & 3.05 & 0.003 & .002 \\
\hline 7 & Assign book reports & 0.46 & 1.16 & 0.30 & 58 & 3.02 & 0.004 & .002 \\
\hline 8 & Use puzzles or word searches & 0.33 & 0.82 & 0.25 & 57 & 3.03 & 0.004 & .002 \\
\hline 13 & Eliminate material mastered & 0.32 & 0.90 & 0.20 & 58 & 2.75 & 0.008 & .002 \\
\hline 23 & Teach a unit on thinking skills & 0.36 & 1.07 & 0.22 & 60 & 2.65 & 0.010 & .002 \\
\hline 10 & Creative writing: student's topic & 0.39 & 1.16 & 0.26 & 58 & 2.58 & 0.012 & .002 \\
\hline 19 & Homework based on ability & 0.30 & 0.98 & 0.22 & 62 & 2.45 & 0.017 & .002 \\
\hline 17 & Locations around classroom & 0.29 & 0.92 & 0.21 & 62 & 2.46 & 0.017 & .002 \\
\hline 21 & Use enrichment centers & 0.34 & 1.10 & 0.19 & 57 & 2.39 & 0.020 & .002 \\
\hline 24 & Competitive thinking skills & 0.30 & 1.05 & 0.20 & 59 & 2.22 & 0.030 & .002 \\
\hline 37 & Higher level questions & 0.21 & 0.78 & 0.18 & 60 & 2.14 & 0.036 & .002 \\
\hline 36 & Ask open-ended questions & 0.23 & 0.90 & 0.18 & 63 & 2.07 & 0.042 & .003 \\
\hline 1 & Use basic skills worksheets & -0.25 & 1.01 & -0.19 & 60 & -1.90 & 0.062 & .003 \\
\hline 30 & Higher grade for instruction & 0.35 & 1.40 & 0.21 & 56 & 1.90 & 0.063 & .003 \\
\hline 4 & Use self-directed kits & 0.38 & 1.48 & 0.21 & 51 & 1.87 & 0.067 & .003 \\
\hline 38 & Encourage discussions & 0.11 & 0.48 & 0.12 & 61 & 1.84 & 0.070 & .003 \\
\hline 9 & Creative writing: teacher's topic & 0.24 & 1.06 & 0.17 & 58 & 1.73 & 0.090 & .003 \\
\hline 35 & Encourage reasoning & 0.18 & 0.85 & 0.18 & 60 & 1.66 & 0.101 & .004 \\
\hline 33 & Programmed materials & 0.25 & 1.27 & 0.16 & 59 & 1.52 & 0.133 & .004 \\
\hline 25 & Contracts for independent study & 0.18 & 1.04 & 0.11 & 60 & 1.35 & 0.181 & .004 \\
\hline 32 & Allocating time & 0.15 & 0.87 & 0.10 & 60 & 1.32 & 0.192 & .005 \\
\hline 20 & Learning centers for basic skills & 0.12 & 0.80 & 0.07 & 59 & 1.12 & 0.266 & .005 \\
\hline 34 & Encourage long range projects & 0.15 & 1.09 & 0.10 & 59 & 1.07 & 0.289 & .006 \\
\hline 22 & Teach thinking in the curriculum & 0.10 & 0.78 & 0.09 & 62 & 0.97 & 0.334 & .006 \\
\hline 31 & Establish interest groups & 0.13 & 1.12 & 0.08 & 53 & 0.85 & 0.397 & .007 \\
\hline 12 & Pretests to determine mastered & 0.10 & 0.91 & 0.07 & 62 & 0.83 & 0.410 & .008 \\
\hline 16 & Alternative instructional formats & -0.11 & 1.24 & -0.09 & 60 & -0.72 & 0.472 & .010 \\
\hline 18 & Other location than classroom & 0.05 & 0.67 & 0.03 & 59 & 0.57 & 0.568 & .013 \\
\hline 29 & Group by ability across class & 0.05 & 0.89 & 0.03 & 61 & 0.43 & 0.672 & .017 \\
\hline 39 & Use computers & 0.03 & 0.75 & 0.02 & 60 & 0.34 & 0.735 & .025 \\
\hline 26 & Time for independent study & 0.03 & 0.80 & 0.02 & 59 & 0.32 & 0.749 & .050 \\
\hline
\end{tabular}


Islamic Principles

The data suggest that when comparing the integration of Islamic values into other curricular areas for gifted students versus average students, teachers were more likely to integrate for gifted students. However, the level at which Islamic values are taught is generally not augmented for gifted students, as "no differences" was always the most frequently occurring response from the teachers (see Table 4).

Further, there are significant differences in presenting Islamic values between gifted and average students on only two items $(\alpha=$ .05); parsing the alpha level using the Holm-Bonferroni sequential method yields no significant results for any item (see Table 5). In addition, a Type I error likelihood was calculated. In this case, we made 45 comparisons; thus, with an alpha level of .05, the probability of getting a Type I error would be .9. Hence, there is a probability that a Type I error could have been made on either of the two items found to be statistically significant. Statically significant differences reported for the two items may be due to probability alone. Considering Cohen's rule of thumb, the effect size values for the 45 items are comparatively small, ranging from .12 to .01 .

These results suggest that Islamic values are presented to gifted students without the content or the instruction of Islamic values being modified to meet gifted students' needs. It could be inferred that Islamic values are more likely to be presented to all students, gifted and average, without differentiation.

\section{Discussion}

Although the majority of the Islamic school teachers believed they had gifted students in their classrooms, only some indicated that they modify their practices to meet gifted students' needs. Further, the degree of modification is limited. The majority of teachers do not differentiate in their strategies among gifted and average students. This finding is consistent with Archambault et al. (1993a, 1993b). However, in this study, mean differences between scores of gifted and average students for each item are higher and have larger effect size than those of the Archambault et al. (1993b) study of the public 


\section{Table 4}

\section{Frequency and Percentages for Teachers' Responses to the TCPAIV Items for Gifted and Average Students}

\begin{tabular}{|c|c|c|c|c|c|c|c|}
\hline \multirow[b]{2}{*}{$\#$} & \multirow[b]{2}{*}{ Item } & \multicolumn{2}{|c|}{ Gifted high } & \multicolumn{2}{|c|}{ Average high } & \multicolumn{2}{|c|}{ No differences } \\
\hline & & $f$ & $\%$ & $f$ & $\%$ & $f$ & $\%$ \\
\hline \multicolumn{8}{|c|}{ Teachers $(n=58)$} \\
\hline 2 & Analyzing parts of Qur'an & 12 & 20.7 & 4 & 6.9 & 34 & 58.6 \\
\hline 8 & Applying the historical concepts & 10 & 17.2 & 2 & 3.4 & 40 & 69.0 \\
\hline 14 & A chance to write about their thoughts & 10 & 17.2 & 1 & 1.7 & 38 & 65.5 \\
\hline 21 & Evaluate reading in the light of Islam & 10 & 17.2 & 2 & 3.4 & 42 & 72.4 \\
\hline 3 & Encouraging students to explore & 9 & 15.5 & 2 & 3.4 & 41 & 70.7 \\
\hline 4 & Connecting Qur'an and a subject area & 9 & 15.5 & 3 & 5.2 & 42 & 72.4 \\
\hline 9 & The social concepts in the Quran & 9 & 15.5 & 2 & 3.4 & 40 & 69.0 \\
\hline 16 & Prophet's teachings and human rights & 9 & 15.5 & 1 & 1.7 & 42 & 72.4 \\
\hline 17 & Prophet's actions and human rights & 9 & 15.5 & 2 & 3.4 & 41 & 70.7 \\
\hline 18 & Reflecting on the prophet's action & 9 & 15.5 & 2 & 3.4 & 43 & 74,1 \\
\hline 12 & Study the universe functions & 8 & 13.8 & 1 & 1.7 & 41 & 70.7 \\
\hline 15 & Discussing human rights in Islam & 8 & 13.8 & 3 & 5.2 & 42 & 72.4 \\
\hline 22 & Islamic and Western concept of ethics & 8 & 13.8 & 1 & 1.7 & 47 & 81.0 \\
\hline 24 & Analyzing Islamic history & 8 & 13.8 & 1 & 1.7 & 45 & 77.6 \\
\hline 31 & Developing a habit of self-evaluation & 8 & 13.8 & 0 & 0.0 & 49 & 84.5 \\
\hline 41 & Developing wisdom & 8 & 13.8 & 3 & 5.2 & 46 & 79.3 \\
\hline 43 & Helping students to think individually & 8 & 13.8 & 3 & 5.2 & 46 & 79.3 \\
\hline 1 & Memorizing parts of Quran & 7 & 12.1 & 3 & 5.2 & 35 & 60.3 \\
\hline 7 & The historical events in the Quran & 7 & 12.1 & 2 & 3.4 & 42 & 72.4 \\
\hline 11 & Reflecting on prophets' lives & 7 & 12.1 & 2 & 3.4 & 42 & 72.4 \\
\hline 13 & The universe functions in Quran & 7 & 12.1 & 2 & 3.4 & 40 & 69.0 \\
\hline 23 & Evaluating personal practices & 7 & 12.1 & 2 & 3.4 & 46 & 79.3 \\
\hline 29 & Cultural practices in the light of Islam & 7 & 12.1 & 2 & 3.4 & 46 & 79.3 \\
\hline 30 & Developing a sense of responsibility & 7 & 12.1 & 2 & 3.4 & 48 & 82.8 \\
\hline 42 & Encouraging questioning and thinking & 7 & 12.1 & 3 & 5.2 & 45 & 77.6 \\
\hline 44 & Protect an Islamic social environment & 7 & 12.1 & 2 & 3.4 & 46 & 79.3 \\
\hline 19 & The concepts of good and bad & 6 & 10.3 & 2 & 3.4 & 49 & 84.5 \\
\hline 20 & The ethical framework in Islam & 6 & 10.3 & 2 & 3.4 & 43 & 74.1 \\
\hline 25 & Develop a sense of awareness & 6 & 10.3 & 2 & 3.4 & 49 & 84.5 \\
\hline 26 & Exploring the Arabic term ilm & 6 & 10.3 & 2 & 3.4 & 45 & 77.6 \\
\hline 28 & Evaluate their daily activities & 6 & 10.3 & 3 & 5.2 & 47 & 81.0 \\
\hline 32 & Self behavior in light of Islamic values & 6 & 10.3 & 3 & 5.2 & 46 & 79.3 \\
\hline 33 & Analyzing Qur'anic verses & 6 & 10.3 & 3 & 5.2 & 45 & 77.6 \\
\hline 35 & The barriers of development & 6 & 10.3 & 3 & 5.2 & 45 & 77.6 \\
\hline 10 & Reflecting on the God's power & 5 & 8.6 & 1 & 1.7 & 44 & 75.9 \\
\hline 27 & Teaching Islamic history & 5 & 8.6 & 2 & 3.4 & 46 & 79.3 \\
\hline 34 & Barriers of personal development & 5 & 8.6 & 2 & 3.4 & 45 & 77.6 \\
\hline 36 & Hadith about personal characteristics & 5 & 8.6 & 3 & 5.2 & 47 & 81.0 \\
\hline 38 & Prophet's behavior with others & 5 & 8.6 & 2 & 3.4 & 48 & 82.8 \\
\hline 39 & Analyzing the effects of environment & 5 & 8.6 & 2 & 3.4 & 48 & 82.8 \\
\hline 5 & The Qur'anic concepts to the daily life & 4 & 6.9 & 2 & 3.4 & 47 & 81.0 \\
\hline 6 & Qur'an and the historical events & 4 & 6.9 & 3 & 5.2 & 43 & 74.1 \\
\hline 37 & Studying prophet's characteristics & 4 & 6.9 & 3 & 5.2 & 48 & 82.8 \\
\hline 40 & The social environment effects & 4 & 6.9 & 2 & 3.4 & 49 & 84.5 \\
\hline 45 & Questioning information resources & 3 & 5.2 & 2 & 3.4 & 49 & 84.5 \\
\hline
\end{tabular}


Table 5

\section{Mean Differences, Standard Deviation, and Level of Significance for Teachers' Responses to the TCPAIV Items for Gifted and Average Students}

\begin{tabular}{|c|c|c|c|c|c|c|c|c|}
\hline$\#$ & Item & $\begin{array}{c}\text { Gif- } \\
\text { Ave }^{2} \\
M\end{array}$ & $\begin{array}{c}\text { Gif- } \\
\text { Ave }^{2} \\
S D\end{array}$ & $E S$ & $t$ & $d f$ & $p$-value & $\begin{array}{c}\text { Adjusted } \\
\alpha\end{array}$ \\
\hline 31 & Developing a habit of self-evaluation & .23 & .68 & .15 & 2.53 & 56 & .009 & .001 \\
\hline 30 & Developing a sense of responsibility & .23 & .80 & .20 & 2.15 & 56 & .036 & .001 \\
\hline 43 & Helping students to think individually & .18 & .71 & .15 & 1.87 & 56 & .067 & .001 \\
\hline 16 & Prophet's teachings and human rights & .19 & .76 & .12 & 1.81 & 52 & .077 & .001 \\
\hline 29 & Cultural practices in the light of Islam & .16 & .71 & .11 & 1.70 & 55 & .095 & .001 \\
\hline 17 & Prophet's actions and human rights & .19 & .86 & .11 & 1.60 & 52 & .115 & .001 \\
\hline 32 & Self behavior in light of Islamic values & .14 & .67 & .10 & 1.59 & 55 & .118 & .001 \\
\hline 18 & Reflecting on the prophet's action & .16 & .76 & .11 & 1.59 & 54 & .118 & .001 \\
\hline 21 & Evaluate reading in the light of Islam & .18 & .86 & .10 & 1.56 & 54 & .124 & .001 \\
\hline 44 & Protect an Islamic social environment & .18 & .86 & .11 & 1.56 & 54 & .124 & .001 \\
\hline 2 & Analyzing parts of Quran & .22 & 1.03 & .15 & 1.50 & 50 & .140 & .001 \\
\hline 22 & Islamic and Western concept of ethics & .18 & .91 & .11 & 1.46 & 56 & 151 & .001 \\
\hline 9 & The social concepts in the Quran & .22 & 1.06 & .12 & 1.45 & 50 & .154 & .002 \\
\hline 8 & Applying the historical concepts & .17 & .92 & .12 & 1.35 & 51 & .182 & .002 \\
\hline 24 & Analyzing Islamic history & .15 & .83 & .09 & 1.31 & 54 & 197 & .002 \\
\hline 11 & Reflecting on prophets' lives & .15 & .85 & .10 & 1.31 & 51 & 197 & .002 \\
\hline 14 & A chance to write about their thoughts & .14 & .76 & .09 & 1.31 & 48 & 197 & .002 \\
\hline 15 & Discussing human rights in Islam & .17 & .97 & .10 & 1.27 & 53 & .211 & .002 \\
\hline 28 & Evaluate their daily activities & .14 & .86 & .12 & 1.24 & 55 & .220 & .002 \\
\hline 34 & velopment & .11 & .67 & .07 & 1.23 & 52 & .224 & .002 \\
\hline 1 & urian & .16 & .71 & .11 & 1.48 & 44 & .225 & .002 \\
\hline 12 & se functions & .14 & .81 & .10 & 1.23 & 49 & .227 & .002 \\
\hline 19 & pts of good and bad & .12 & .77 & .10 & 1.19 & 57 & .240 & .002 \\
\hline 41 & Developing wisdom & .14 & .89 & .09 & 1.18 & 57 & .242 & .002 \\
\hline 4 & cting $Q u$ rian and a subject area & .15 & .91 & .10 & 1.18 & 54 & .242 & .002 \\
\hline 33 & Analyzing Qur'anic & .11 & .69 & .07 & 1.18 & 54 & .243 & .003 \\
\hline 23 & Evaluating personal practices & .15 & .93 & .09 & 1.16 & 54 & .252 & .003 \\
\hline 42 & Encouraging questioning and thinking & .13 & .81 & .08 & 1.15 & 55 & .253 & .003 \\
\hline 36 & Hadith about personal characteristics & .09 & .64 & .06 & 1.04 & 55 & .301 & .003 \\
\hline 3 & Encouraging students to explore & .13 & .92 & .09 & 1.04 & 52 & .301 & .003 \\
\hline 25 & ense of awareness & .11 & .79 & .08 & 1.00 & 56 & .322 & .003 \\
\hline 26 & Exploring the Arabic term ilm & .09 & .69 & .05 & 1.00 & 52 & .322 & .003 \\
\hline 20 & The ethical framework in Islam & .1 & .69 & .05 & 1.00 & 51 & .322 & .004 \\
\hline 27 & Teaching Islamic history & .09 & .73 & .06 & 0.93 & 53 & .358 & .004 \\
\hline 35 & The barriers of development & .09 & .75 & .06 & 0.9 & 54 & .374 & .005 \\
\hline 7 & The historical events in the Qur'an & .12 & .98 & .08 & 0.85 & 51 & .401 & .005 \\
\hline 40 & The social environment effects & .09 & .79 & .06 & 0.84 & 55 & .403 & .006 \\
\hline 5 & The Qur'anic concepts to the daily life & .09 & .81 & .07 & 0.84 & 53 & .403 & .006 \\
\hline 10 & Reflecting on the God's power & .04 & .79 & .06 & 0.84 & 50 & .403 & .007 \\
\hline 13 & The universe functions in Qur'an & .07 & .81 & .08 & 0.84 & 48 & .404 & .008 \\
\hline 39 & Analyzing the effects of environment & .14 & .89 & .04 & 0.66 & 54 & .510 & .010 \\
\hline 37 & Studying prophet's characteristics & .13 & .81 & .03 & 0.47 & 55 & .644 & .013 \\
\hline 6 & Qur'an and the historical events & .18 & .71 & .04 & 0.44 & 50 & .659 & .017 \\
\hline 38 & Prophet's behavior with others & .18 & .86 & .02 & 0.34 & 55 & .735 & .025 \\
\hline 45 & Questioning information resources & .02 & .60 & .01 & 0.23 & 53 & .821 & .050 \\
\hline
\end{tabular}

${ }^{2}$ Gif-Ave refers to the mean differences between teachers' reports of the frequency use with gifted and the frequency of use with average students and the standard deviations for those mean differences. $\mathrm{ES}=$ Effect size. 
schools sample. The Archambault et al. (1993b) sample was a large one that consisted of teachers of diverse backgrounds from various parts of the United States from both public and private schools. Therefore, although the general pattern of limited differentiation in the classroom holds true for the Muslim sample in most cases, the teachers in the Islamic schools apparently are doing more differentiation than was found in a national sample. This could be because the entire sample was from private schools; although in the national survey, differentiated treatment was lower for private schools than for public schools. Another possible explanation is that, given the time lapse since the Archambault et al. (1993b) study, perhaps differentiation is now more acceptable than it was at the time of the national survey.

Teachers at Islamic schools appear to be limited in their choice of differentiation strategies. Teachers reported that they use acceleration, enrichment, worksheets, and have their gifted students help tutor. However, it is not clear that the term differentiation as used in gifted education research reflects the same practices in the Islamic schools.

Teachers at the Islamic schools present Islamic values to all students without differentiation between gifted and average. The identical treatment of students with different abilities limits Muslim gifted students from establishing a deeper understanding of the Qur'an and Hadith. According to Ashraf (as cited in Sahadat, 1997), the sense of responsibility for the use of knowledge and accountability for the exercise of one's will would be better understood from a context of a Muslim's relationship with almighty Allah. The growth of this relationship could be achieved by the continuous development of the person's knowledge. The more educated a person is, the more likely the person is to achieve a higher sense of accountability and develop a closer relationship with almighty Allah. According to the Holy Qur'an, "Those truly fear Allah, Among His Servants, Who have knowledge: For Allah is Exalted in Might, Oft-Forgiving" (35:28). Therefore, differentiation would help to broaden gifted students' ability by providing them with different educational opportunities appropriate to their attained levels of learning. In the Holy Qur'an, almighty Allah states, "Say: If the ocean were Ink (wherewith to write 
out) The words of my Lord. Sooner would the ocean be Exhausted than would the words Of my Lord, even if we Added another ocean Like it, for its aid" (18:109). This Qur'anic verse does not merely illustrate that the ultimate source of knowledge is inestimable, it also invites the scholar to broaden his or her perspectives and strive to fathom as much as he or she can of Allah's worlds. Hence, the use of differentiating strategies will have a great impact in advancing gifted students' knowledge and providing them with the elements to strive to achieve more.

\section{References}

Aickin, M., \& Gensler, H. (1996). Adjusting for multiple testing when reporting research results: The Bonferroni vs Holm methods. American Journal of Public Health, 86, 726-728.

Al-Otaibi, M. M., \& Rashid, H. M. (1997). The role of Islamic society: Historical and contemporary perspectives. The American Journal of Islamic Social Sciences, 14(4), 1-18.

Archambault, F. X., Jr., Westberg, K. L., Brown, S. W., Hallmark, B. W., Zhang, W., \& Emmons, C. L. (1993a). Classroom practices used with gifted third and fourth grade students. Journal for the Education of the Gifted, 16, 103-119.

Archambault, F. X., Jr., Westberg, K. L., Brown, S. W., Hallmark, B. W., Emmons, C. L., \& Zhang, W. (1993b). Regular classroom practices with gifted students: Results of a national survey of classroom teachers (Research Monograph 93102). Storrs, CT: University of Connecticut, The National Research Center on the Gifted and Talented.

Badawi, H. (2005). Parental reasons for school choice: A case study of an Islamic school in the United States of America. Dissertation Abstracts International, 66(02) 535A. (UMI No. 3165875)

Clark, B. (2002). Growing up gifted. Upper Saddle River, NJ: Person Education.

Delcourt, M. A. B., Loyd, B. H., Cornell, D. G., \& Goldbern, M. D. (1994). Evaluation of the effects of programming arrangements on student learning outcomes (Research Monograph 94108). 
Storrs, CT: University of Connecticut. (ERIC Document Reproduction Service No. ED388018)

Elkhaldy, F. Y. (1996). Analysis of parental choice: Islamic school enrollment in Florida. Dissertation Abstracts International, 57(7), 2947A. (UMI No. 9638566)

Elsegeiny, S. K. (2005). American Muslim school leadership: Principal and teacher perspectives. Dissertation Abstracts International, 66(05), 1574A. (UMINo. 3175817)

Gentry, M., Gable, R. K., \& Springer, P. (2000). Gifted and nongifted middle school students: Are their attitudes toward school different as measured by the new affective instrument, My Class Activities ... ? Journal for the Education of the Gifted, 24, 74-96. Glass, G. V., \& Hopkins, K. D. (1995). Statistical methods in education and psychology. Needham Heights, MA: Simon \& Schuster Adult Publishing Group.

Howell, D. C. (2002). Statistical methods for psychology. Pacific Grove, CA: Duxbury Press.

Istanbouli, M. (2000). An exploration case study of religion-cultural issues in an Islamic school: Implications for socialization and enculturation. Dissertation Abstracts International, 60(12), 4287A. (UMI No. 9955390)

Johnsen, S. K., Haensly, P. A., Ryser, G. R., \& Ford, R. F. (2002). Changing general education classroom practices to adapt for gifted students. Gifted Child Quarterly, 46, 45-63.

Khan, A. N. (1983). The education system in Muslim India: A historical perspective. Pedagogical Historical, 23(1), 67-83.

Parker-Jenkins, M. (1995). Children of Islam. Exeter, UK: BPC Wheatons.

Purcell, J. H. (1993). The effects of the elimination of gifted and talented programs of participating students and their parents. Gifted Child 2uarterly, 37, 177-187.

Roback, P. J., \& Askins, R. A. (2005). Judicious use of multiple hypothesis tests. Conservation Biology, 19, 261-267.

Sahadat, J. (1997). Islamic education: A challenge to conscience. The American Journal of Islamic Social Sciences, 14(4), 19-34.

Selby, K. L. (1994). An integrated versus a history-centered arrangement of social studied content used by full-time Islamic schools 
in the United States. Dissertation Abstracts International, 55(5), 1188A. (UMI No. 9423313)

Westberg, K. L., Archambault, F. X., Jr., Dobyns, S. M., \& Salvin, T.

J. (1993). The classroom practices observation study. Journal for the Education of the Gifted, 16, 120-146.

Yusuf'Ali, A. (1995). The meaning of the Holy Qur'an. Beltsville,

MD: Amana.

\section{End Notes}

1 The Holy Qur'an is arranged in 114 Surabs (chapters). Each Surah consists of a number of Ayab (verse). The most convenient form to name Surah and Ayah is (96:1) which means the number 96 Ayah from the first Surah (Yusuf'Ali, 1995).

2 To show their respect, Muslims use the phrase "Peace be upon him" after they say or write Prophet Mohammad's name. In this research, I have chosen to indicate this with the parenthetic phrase (pbuh). A similar phrase "Peace be upon him" is used whenever Muslims say or write the names of other prophets. 


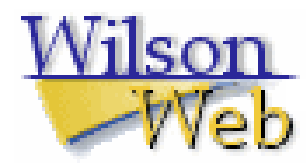

\section{COPYRIGHT INFORMATION}

TITLE: Differentiation for the Gifted in American Islamic Schools

SOURCE: J Educ Gifted 30 no4 Summ 2007

The magazine publisher is the copyright holder of this article and it is reproduced with permission. Further reproduction of this article in violation of the copyright is prohibited. To contact the publisher: http://www.prufrock.com/ 